Institute of $\mathbf{F}_{\text {ood and }} \mathbf{A}_{\text {gricultural }} \mathbf{S}_{\text {ciences }}$

\title{
Your Florida Dooryard Citrus Guide - Common Pests, Diseases, and Disorders of Dooryard Citrus ${ }^{1}$
}

James J. Ferguson ${ }^{2}$

You've probably already noticed that Florida's humid climate harbors all kinds of fungi and creepy crawlies. The good news is, like most of us, they don't change very much. Once you learn to recognize the major pests, diseases and disorders of citrus, you'll be able to identify them easily.

Strategies to control citrus pests include biological control, integrated pest management, and chemical control. In most cases, naturally occurring, biological control (letting nature take its course) is the easiest and best way for homeowners. Integrated pest management (IPM) involves a combination of biological control, cultural practices, and pesticides, when needed. Chemical control (application of pesticides) is quick but can upset biological control systems and demands strict adherence to label instructions. Never hesitate to consult your county extension horticultural agent for additional information on identification and management of citrus diseases, pests and disorders, even before they threaten to destroy or seriously damage your citrus tree.

Many of the pathogens and pests discussed here become active and increase in numbers in spring when citrus trees develop new leaves, shoots, and fruit. Once you identify these problems, it may be too late to do anything for the current season. But, again like us, the pathogens and pests discussed here have a weak point - a fatal flaw-that I'll point out as the best management strategy. You can see what these pests, diseases, and disorders look like by turning to the pictures included of this manual.

\section{Diseases}

The most common fungal diseases of citrus in Florida are greasy spot, melanose, scab, and foot rot. The first three affect fruit, leaves, and twigs; the fourth, a disease of the "foot" of the tree, near ground level, directly affects the trunk of the tree. Over time, foot rot can weaken the entire tree.

\section{Greasy Spot}

Imagine you injected drops of old, dirty engine oil below the surface of citrus leaves-you'd see "greasy spots," the kind dry cleaning can't get out of a white shirt or blouse after youve changed a flat tire. These grease spots are actually leaf tissue that has collapsed after infection by the greasy spot fungus (Figure 1).

1. This document is HS 890, one of a series of the Horticultural Sciences Department, Florida Cooperative Extension Service, Institute of Food and Agricultural Sciences, University of Florida. Originally published in hardcopy, 1995. Publication date: August, 2002. Please visit the EDIS Web site at http://edis.ifas.ufl.edu.

2. James J. Ferguson, professor, Horticultural Sciences Department, Cooperative Extension Service, Institute of Food and Agricultural Sciences, University of Florida, Gainesville, 32611.

The Institute of Food and Agricultural Sciences is an equal opportunity/affirmative action employer authorized to provide research, educational information and other services only to individuals and institutions that function without regard to race, color, sex, age, handicap, or national origin. For information on obtaining other extension publications, contact your county Cooperative Extension Service office. Florida Cooperative Extension Service/Institute of Food and Agricultural Sciences/University of Florida/Christine Taylor Waddill, Dean. 
Citrus leaves function for 2 to 3 years before they drop. When foliage is heavily infected, severe leaf drop can occur prematurely (Figure 2), resulting in a gradual reduction in tree vigor. Weakened trees become more susceptible to other diseases and pests, as well as to additional cold damage.

The main impact of greasy spot is reduction of tree vigor. External fruit quality can also be affected. Look for pinpoint black specks on the rind, especially on grapefruit, lemons, and tangelos (Figure 3). (Sweet oranges and mandarins are less susceptible.) Greasy spot can be distinguished from melanose, a disease covered later on, by using a hand lens to see where the black spots occur. Greasy spot lesions do not cover the oil glands on the fruit rind; melanose lesions do.

Greasy spot is a lazy, summer disease in that infected, fallen leaves decompose during the summer rains and produce inoculum for one to four months to infect leaves that will drop the following spring. Once you have greasy spot, the cheapest, simplest, most effective control strategy is to remove and destroy fallen citrus leaves near the infected tree. Don't use infected leaves as mulch around your tree. Don't bury them. Make sure theyre destroyed before summer rains occur. Oil and copper sprays can also control greasy spot.

\section{Citrus Scab}

Scab is undoubtedly the ugliest disease of citrus, appearing as a rash of scabs or warts on leaves, twigs, and fruit (Figure 4). Since new generations of inoculum (infectious material) can be produced within five days, scab is a "compound-interest" disease that can spread rapidly, given the right conditions, from overwintering infections on leaves and stems. Compared with the greasy spot fungus, the scab organism is an aggressive pathogen, with the first seasonal infection usually occurring with early spring cold fronts accompanied by rain during March and April. Water from rain, overhead irrigation and dew is, in fact, the most important factor affecting disease development.

Early stages of scab infection include well-defined, conical growths on one side of the leaf with a corresponding conical depression on the

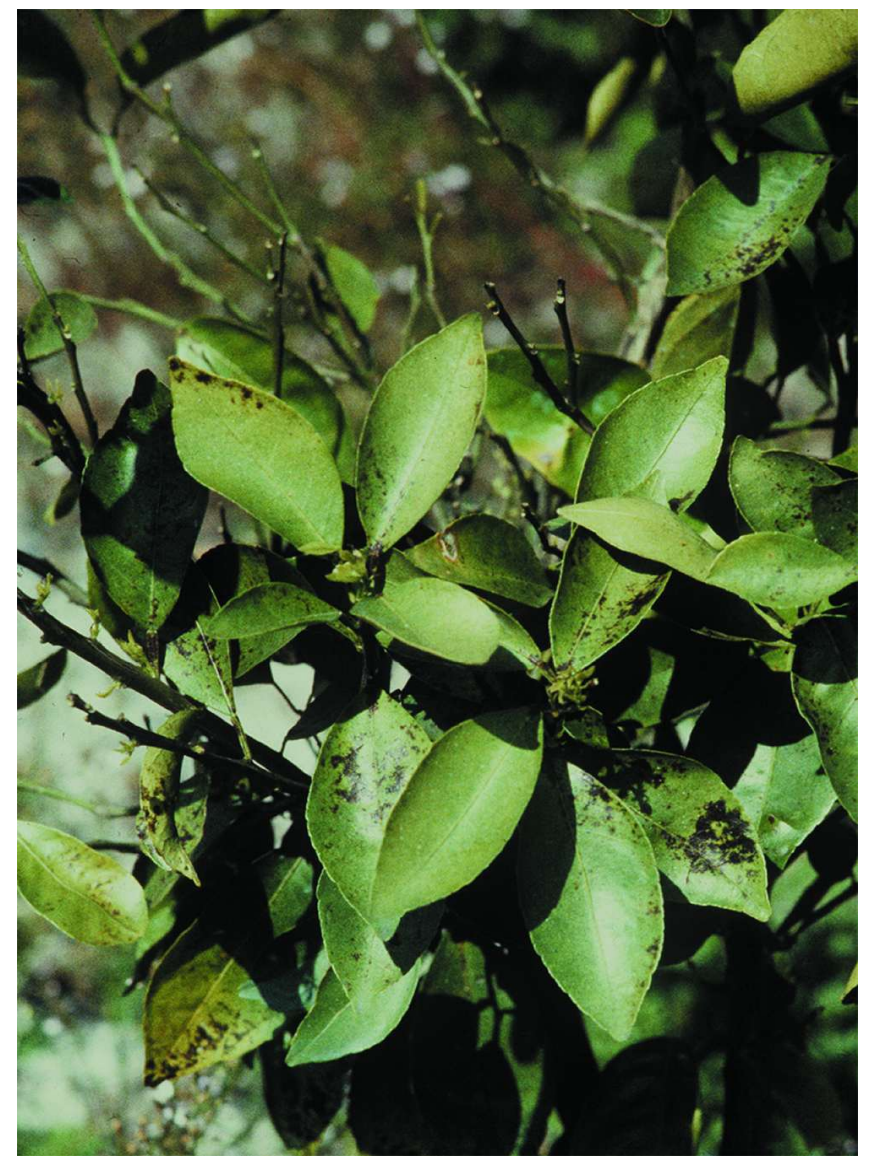

Figure 1. Greasy Spot symptoms on leaves.

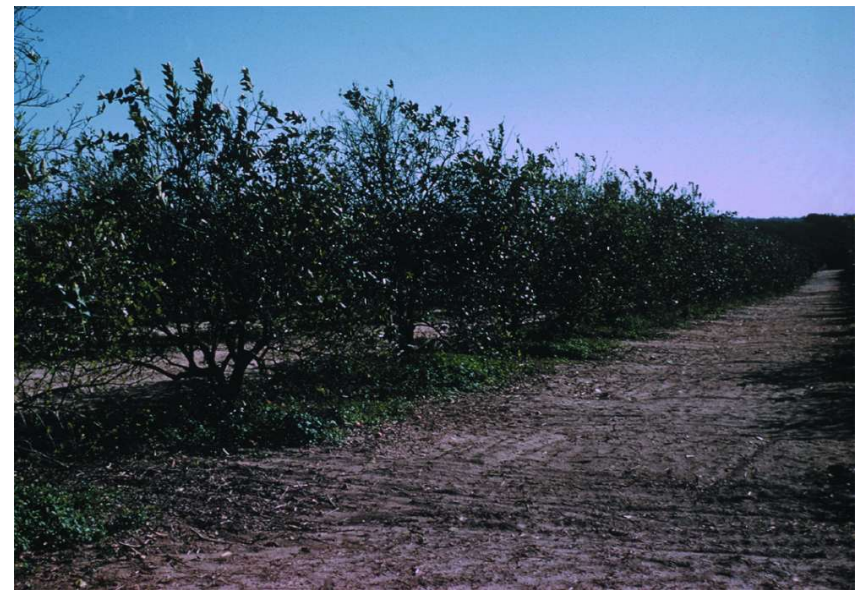

Figure 2. Heavy greasy spot infections cause severe leaf drop, reducing tree vigor.

opposite side. These lesions may occur singly or be grouped irregularly (Figure 4). The crests of these wart-like growths usually become covered with a scabby tissue ranging in color from pale to dark. Infected spots often run together and cover large areas with a corky, scab-like growth. Badly infected leaves and twigs become distorted and stunted. When fruit is infected when very young, it can become 


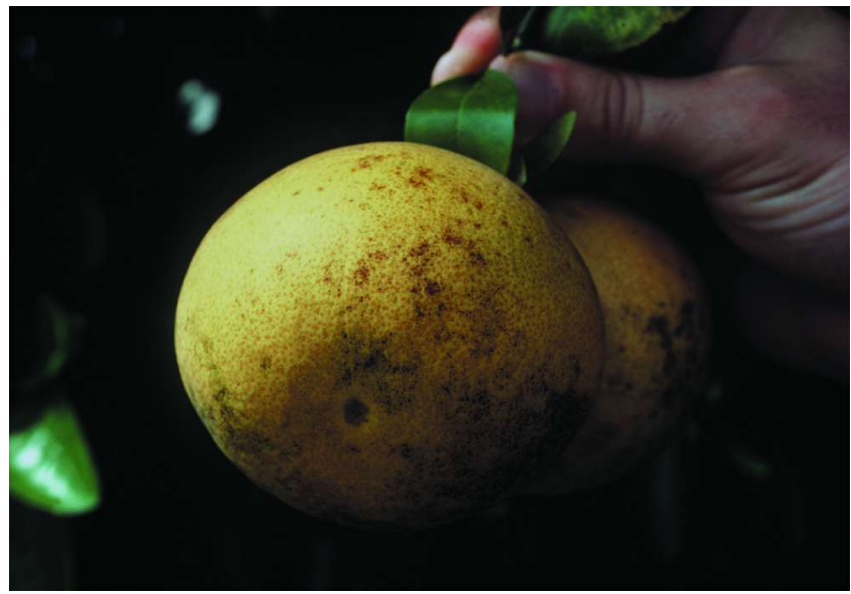

Figure 3. Greasy Spot rind blotch on grapefruit.

misshapen, with warty growths or projections, especially on Temples (Figure 5). However, interior fruit quality is usually not affected. The lighter coloring of the lesions usually distinguishes citrus scab from melanose, which may also distort young leaves.

Susceptible cultivars include Temple oranges, lemons, Minneola tangelos, Murcotts, and Page oranges. Other cultivars like satsuma tangerines, Orlando tangelos, Tahiti limes, and grapefruit are less susceptible. The best scab management strategy is to remove and destroy the source (infected leaves, twigs, and fruit) of inoculum, controlling the disease before it develops momentum.

Since scab also occurs on some rootstocks (sour orange, rough lemon, Rangpur lime, trifoliate orange, and Carrizo citrange), this disease is commonly introduced into the home landscape on already infected nursery trees.

When buying a nursery tree, carefully examine the leaves for disease lesions and evidence of insect damage and eggs. It may be worth your while to remove all infected leaves, twigs and fruit, if possible. In this way you can avoid introducing the pathogen or pest into your dooryard.

Avoid overhead irrigation that spreads scab. Install drip or micro- sprinkler irrigation. Copper sprays also can be applied 2-3 weeks after petal fall, and again 2-3 weeks later to control scab.

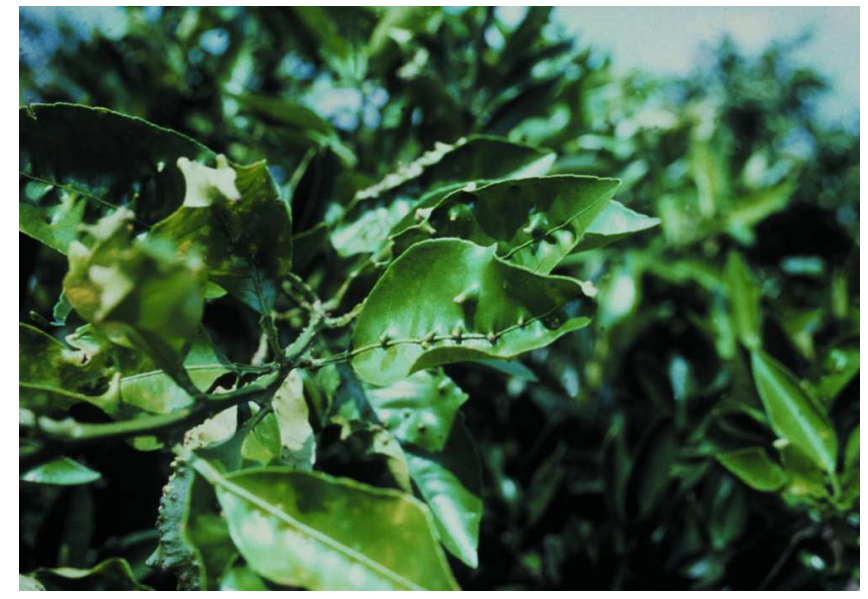

Figure 4. Scab: cone-like distortions on leaves.

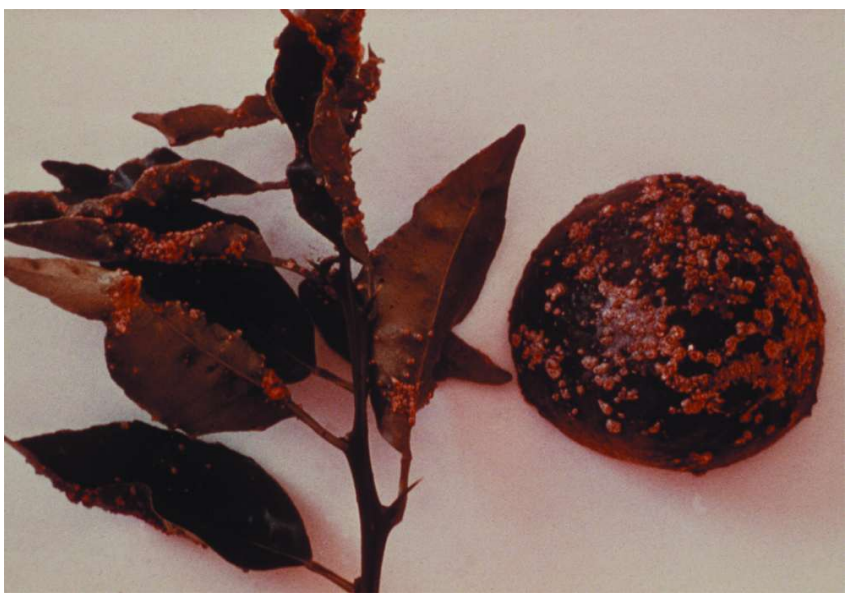

Figure 5. Scabs or warts on leaves, twigs and fruit.

\section{Melanose}

The most recognizable symptoms of melanose are small, dark brown, raised lesions on leaves that have a rough, sandpaper texture (Figure 6). When the fungal spores stream down the surface of fruit, a "tear-streaking" symptom develops (Figure 7). When smaller lesions coalesce to form a large one, a "mudcake" lesion develops (Figure 8).

Melanose lesions on leaves and fruit are actually scar tissue formed when the host plant walls off infections. Both rust mite blemishes and melanose lesions on fruit are brown but melanose lesions have a rougher texture. Melanose lesions can also be distinguished from greasy spot lesions on fruit by observing lesions with a hand lens. Melanose lesions cover oil glands on the fruit surface but greasy spot lesions do not. 
Inoculum is produced only on recently killed twigs. Rain or overhead irrigation splashes inoculum onto leaves and fruit from April to June. For this reason, melanose is usually more severe in older, neglected trees and cold-damaged trees with large amounts of dead wood and twigs.

All cultivars are affected by melanose, but fortunately it does not cause leaf drop and fruit damage is only superficial. Leaves are susceptible until fully expanded and fruit is susceptible for 12 weeks after petal fall. Copper sprays are usually applied 2-3 weeks after petal fall and a second spray 2-3 weeks later.

The best melanose management strategy is to remove small, dead twigs, and avoid overhead irrigation. If this is impractical, either spray with copper or don't spray and live with melanose, since it has little serious impact on mature trees.

Another form of the melanose fungus causes a post-harvest fruit rot. So if you plan to harvest and send fruit to your sister in Saskatchewan, control may be necessary.

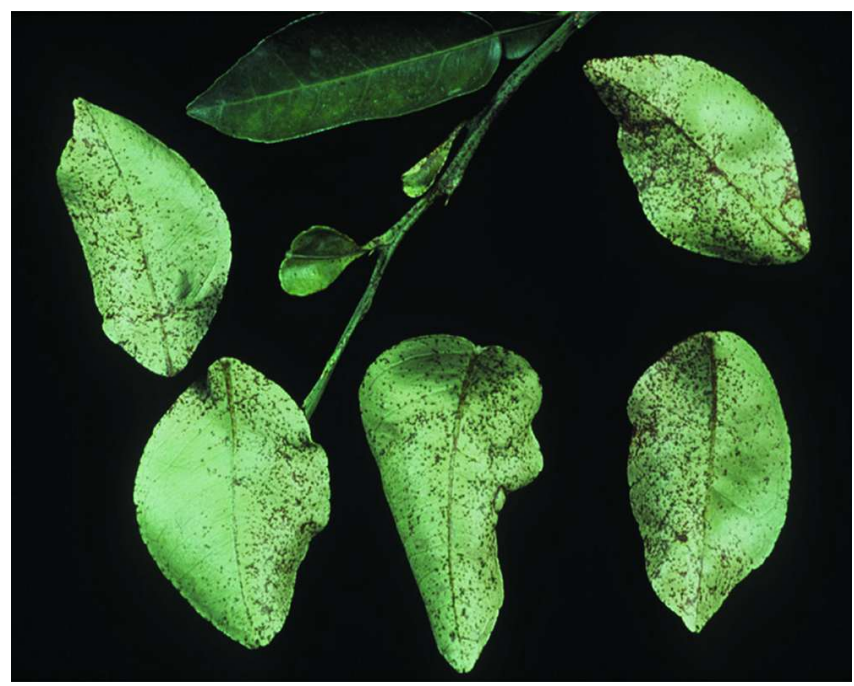

Figure 6. Melanose symptoms - leaf lesions with rough, sandpaper texture.

\section{Foot Rot}

Remember, one of the advantages of a budded tree (consisting of a scion/rootstock combination) is resistance to diseases. Foot rot may well be the most common soilborne disease affecting citrus scions, rootstocks and even seedling trees. Actually, you can

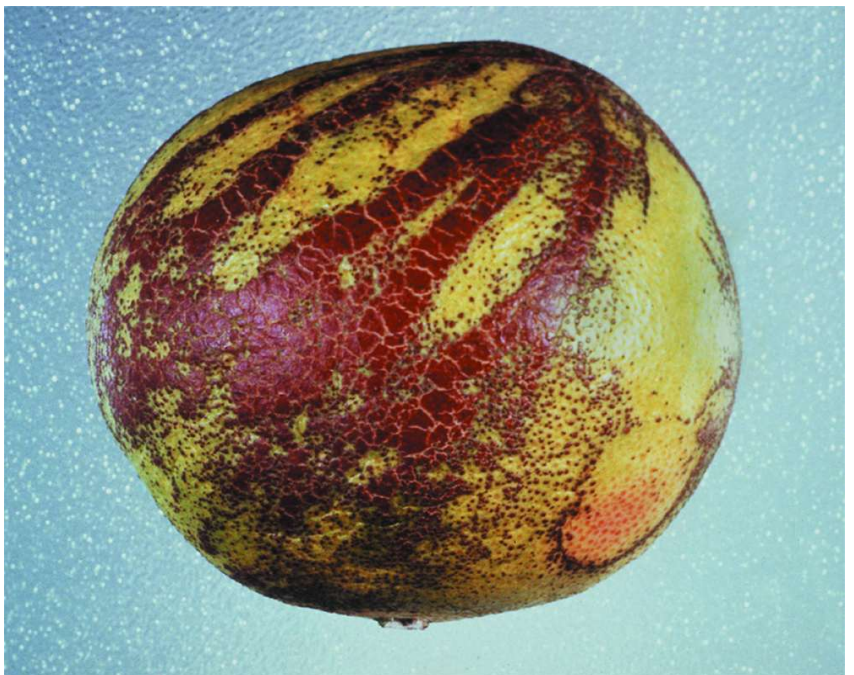

Figure 7. Melanose - tear-streaking symptoms on fruit.

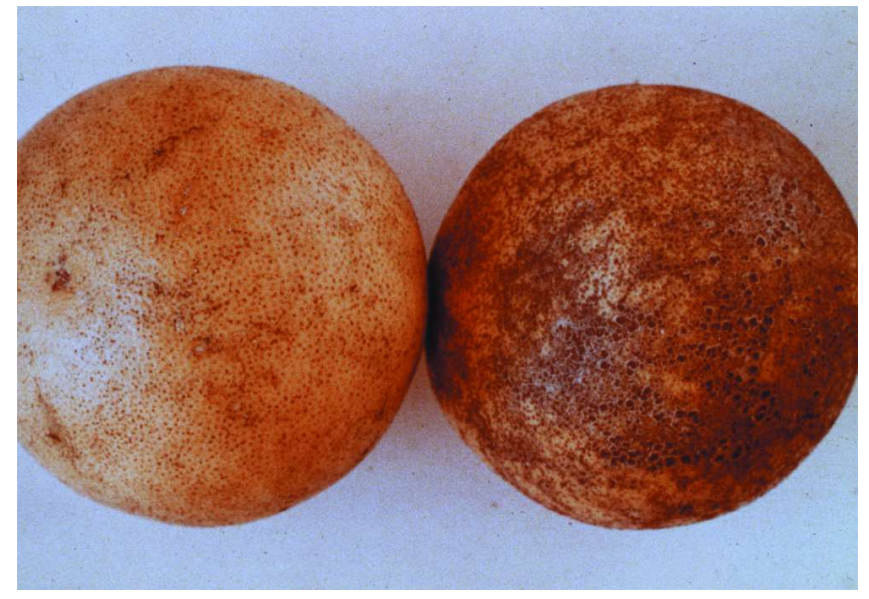

Figure 8. Melanose - mudcake lesions on fruit at right.

have root rot, foot rot, and a fruit rot on the same tree, caused by a widely distributed fungus with a nearly unpronounceable name, Phytophthora, meaning plant destroyer.

Foot rot can affect only the scion, only the rootstock, or both scion and rootstock-if both are susceptible - and seedling trees. Foot rot lesions usually begin near the budunion, expanding either upward on the trunk or downward into the root crown (large exposed roots at the base of the trunk).

The first symptoms of foot rot are water soaking of the bark in irregular patches and oozing of varying amounts of gum. Over time, the diseased bark dries out, settles, cracks and weathers off, with the wood beneath the bark staining brown (Figure 9, Figure 10). Some healing may take place, with callus or scar tissue forming around the healthy margin of the lesion, limiting further progress of the disease. 
Canopy symptoms are the same as those produced by any factor that disrupts the flow of water and nutrients from the roots to the canopy: nutrient deficiency symptoms, especially nitrogen, reduction in leaf and fruit size, leaf drop and dieback, and a general reduction in tree vigor (Figure 11).

The root rot phase of the disease is characterized by decomposition of the fine, fibrous feeder roots near the soil surface. Phytophthora can also cause brown rot of fruit, which is characterized by a light brown discoloration of the fruit rind or peel. This discolored area remains firm and leathery, but under humid conditions, white fungal growth will appear on the fruit surface and the fruit will smell rancid. Brown rot is usually associated with extended periods of rainfall and wetting caused by slow moving tropical storms or hurricanes. Since such conditions are more likely to occur in the early fall than later in the season, brown rot is found more frequently on early maturing cultivars, such as Hamlin oranges and grapefruit. Since the fungal spores that cause this disease are splashed from the soil onto the fruit, pruning low-hanging branches can prevent brown rot. You might lose some fruit, but you will also prevent the disease from spreading higher up into the tree.

The fungus that causes these diseases belongs to a group of organisms called "water molds," which do well under high soil moisture, but not flooded conditions. Symptoms usually occur after heavy rains or excess irrigation has favored infection of susceptible plant tissue. If planting in soil that has naturally poor drainage, especially in the "flatwoods" area of southern Florida, plant your tree higher than usual by creating a mound or raised bed that will allow good drainage, even under flooded conditions. Be sure to plant your tree with the budunion at least 4 to 6 inches above the soil line.

Although mulching can prevent weed growth and conserve water, piling mulch up against the tree trunk can predispose your tree to infection by limiting air circulation and providing a path for the fungus from the soil to susceptible scion tissue above the budunion.

Anything you can do to encourage air circulation at the base of the tree will help, including pruning low hanging branches that scrape the ground and removing plant and soil debris from the trunk and crown roots. Since this fungus usually penetrates through wound tissue, don't wound or scrape the bark at the base of the tree when you're hoeing or mowing.

The only rootstocks resistant to foot rot are trifoliate orange, Citrus macrophylla and Swingle citrumelo. Sour orange and Carrizo citrange are tolerant, while Cleopatra mandarin, rough lemon, Milam, Volkamer lemon and Rangpur and Palestine sweet lime vary from tolerant to susceptible. Sweet orange is generally considered the most susceptible when used as a scion, rootstock or seedling tree.

If your tree has already developed foot rot, scrape off the brown, discolored bark and surface wood until you reach healthy wood and paint the exposed area with a copper paint. Systemic fungicides are also available.

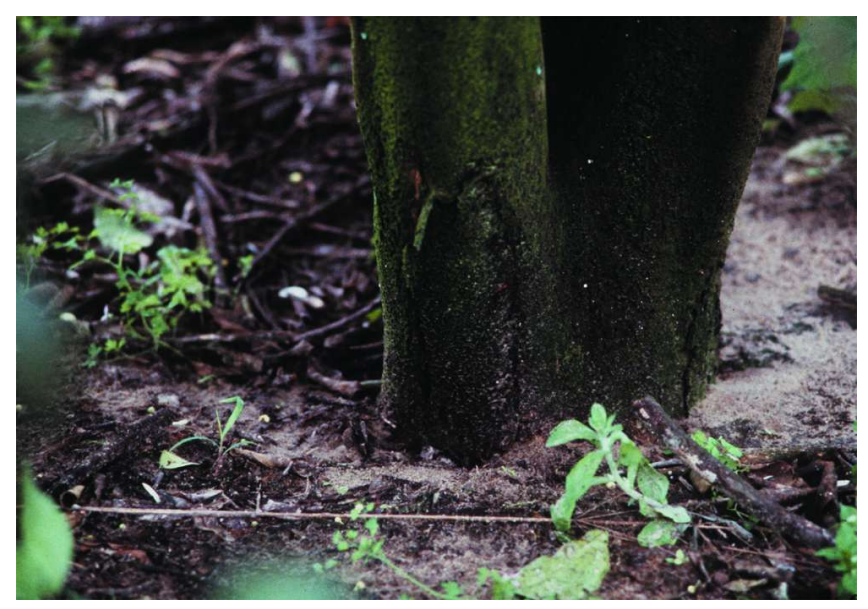

Figure 9. Foot rot bark lesions.

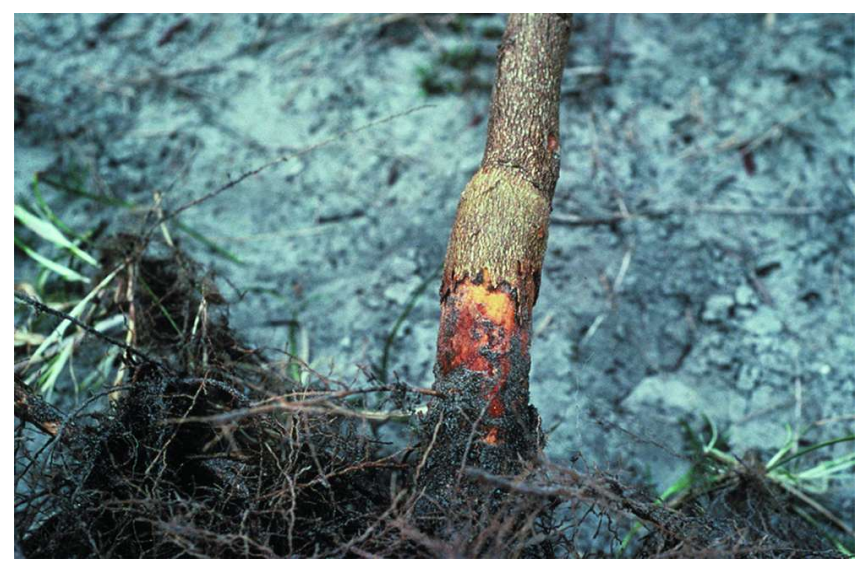

Figure 10. Foot rot - brown stains beneath the bark. 


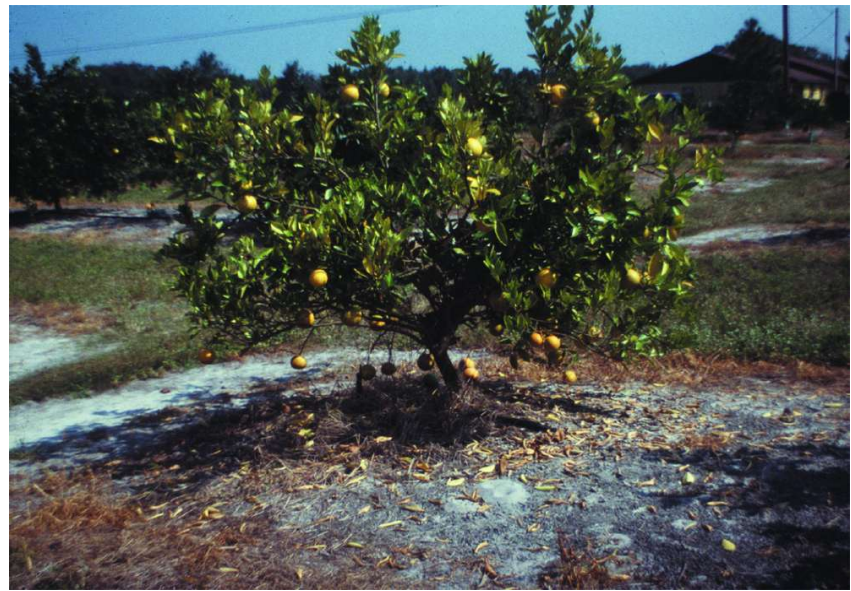

Figure 11. Foot rot symptoms - general tree decline.

\section{Other Diseases}

Other fungus diseases like Alternaria brown spot and post-bloom fruit drop cause fruit drop from time to time. Alternaria brown spot affects Dancy tangerines and Minneola tangelos most seriously, and can produce leaf spots, leaf drop, fruit spots (Figure 12) and fruit drop. Like most of the other fungal diseases, copper sprays can control it.

Post-bloom fruit drop has occurred widely on all cultivars in some years, especially when heavy rain, overhead irrigation, dew, or fog wets blossoms. Blossoms develop peach- to orange-color lesions and young fruit drop soon after fruit set, leaving a "button," the remains of the flower parts (Figure 13). From 50 to $90 \%$ of a crop can be lost. Systemic fungicides are applied commercially, but for the homeowner, little can be done except avoiding overhead irrigation during bloom. Sooty mold, a black, superficial fungal growth on leaves, twigs and fruit, grows on exudates from aphids, whiteflies, soft scales and other piercing, sucking insects (Figure 14). Sooty mold does little damage and can easily be washed off fruit. Oil sprays will also loosen this mold from leaves and twigs.

A number of viral diseases, causing bark scaling on the rootstock or scion, stunting, tree decline and death, also occur in Florida. Once a tree is infected, little can be done. Your best defense is to buy healthy, vigorous trees from a reputable nursery.

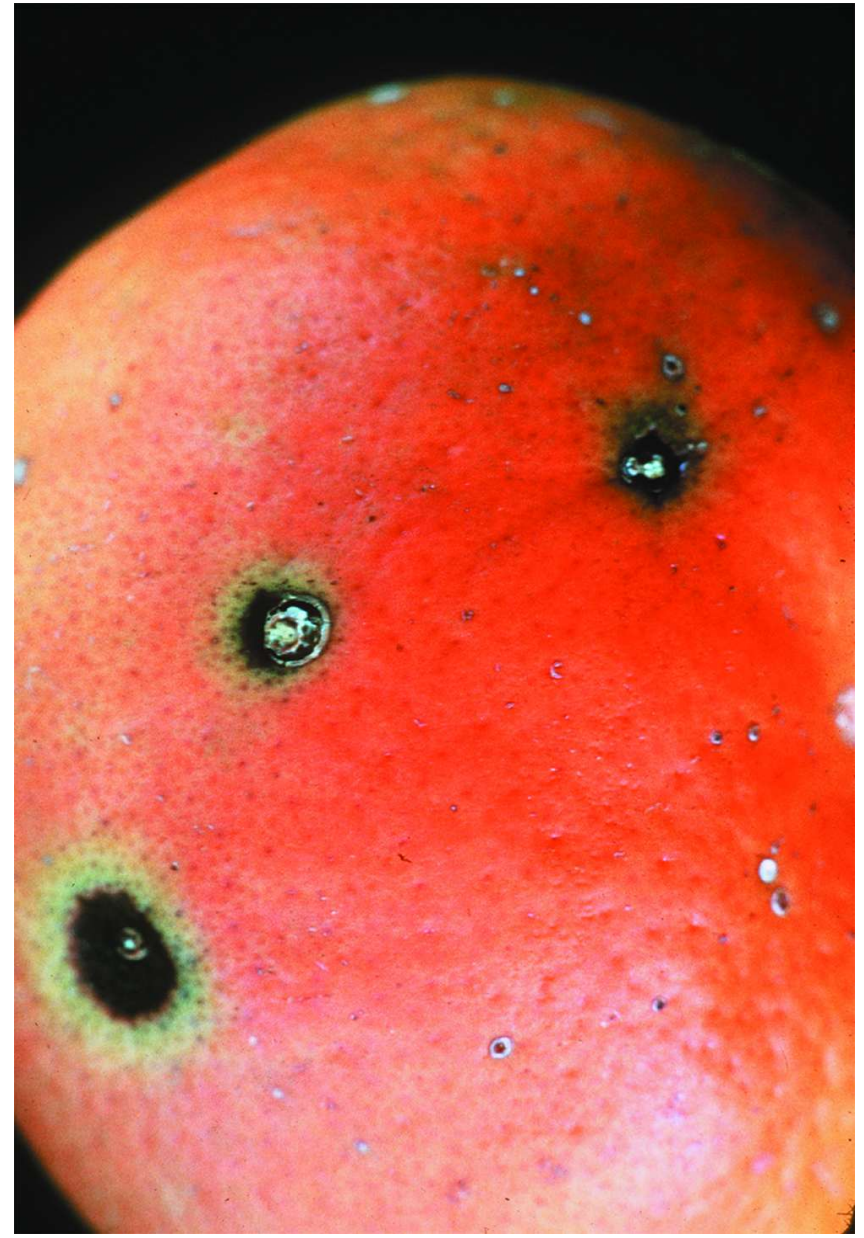

Figure 12. Alternaria Brown Spot on fruit.

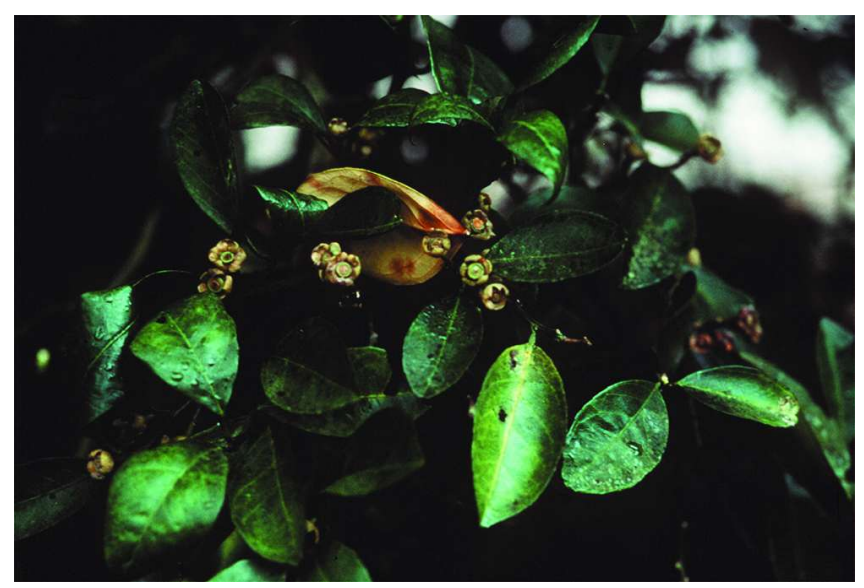

Figure 13. Post-bloom fruit drop: leaves a persistant calyx or "button" and distorted leaves with enlarged veins.

\section{Pests}

The most common pests of dooryard citrus include aphids, whiteflies, fire ants, mites, scales, plant bugs, and chewing insects like grasshoppers, katydids, and caterpillars. Descriptions of the organisms and the damage they cause are included 


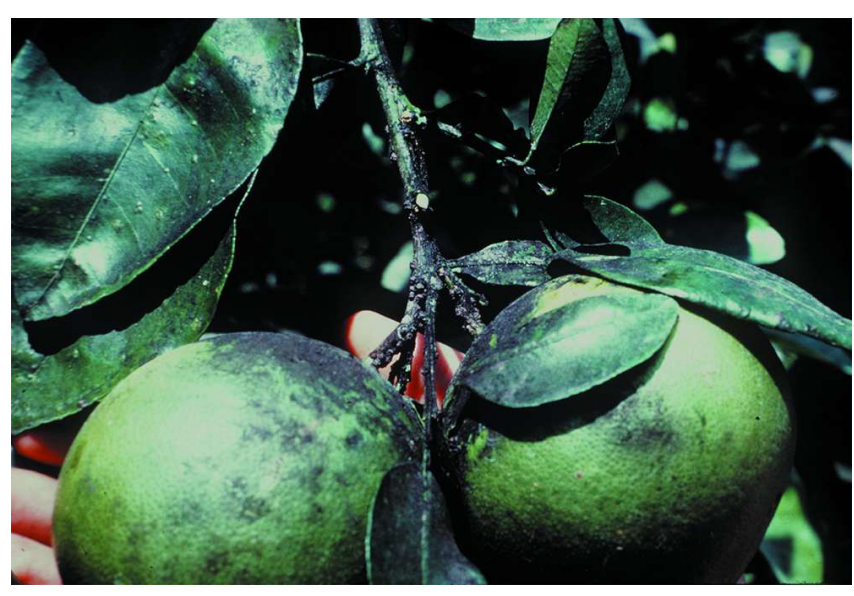

Figure 14. Sooty mold washes off easily from leaves and fruit.

here. Consult your county extension agent for recommended chemical controls.

You can usually depend on aphids and whiteflies to attack young, succulent leaves and shoots in the spring. When aphids feed, they cause young leaves and shoots to cup, curl and distort, reducing the growth of that particular flush (Figure 15). Usually the damage is done before you notice it, so it's important to watch for early signs of infestation. Young trees can be stunted if severe infestation retards canopy development. But in most cases, trees can tolerate aphids and survive.

Whiteflies also infest young leaves and flushes, sucking the sap from these tissues. But no leaf or shoot distortion occurs (Figure 16). Friendly orange-red fungi parasitizes immature whiteflies (Figure 17), so don't be alarmed when you see these good guys on the bottom leaf surface. However, if you apply copper sprays to control greasy spot, melanose, and scab, the copper spray will also destroy friendly fungi. Fire ants can kill young trees by eating the tender bark of the roots and trunk and branches, especially those of grapefruit (Figure 18).

Mites, especially rust mites and spider mites, feed on leaves and fruit, causing a variety of symptoms referred to as stippling, silvering and russeting. Mites can barely be seen with the naked eye but can be readily observed with a hand lens. Rust mites are yellow and wedge-shaped; spider mites actually look like tiny spiders. Populations of rust mites usually increase in the humid summer and again, to a lesser degree, in the fall, causing a russeting of leaves and a russeting and brown staining of fruit (Figure 19). While feeding on fruit, rust mites avoid shade and move towards light but avoid direct sunlight, often resulting in heavily stained fruit with clearly defined, sunlight areas without damage (Figure 20). Excessive damage can lead to leaf drop. Infested fruit may be smaller at harvest but may be sweeter because fruit sugar may be more concentrated due to water loss from feeding injuries.

Often, a naturally occurring fungus (Hirsutella) acts as a biological control of citrus rust mites, but this beneficial fungus may not reduce rust mite populations until after damage has been done.

Populations of spider mites usually peak in dry spring and fall months, causing leaves to have a lightly colored, scratched look called stippling or etching that can lead to leaf drop-especially on very susceptible cultivars like Sunburst tangerines (Figure 21). These pests can also cause leaf blistering and distortion and leaf drop.

What about scales? Another common insect pest, immature scales insert their piercing-sucking mouthparts into host tissue. They remain fixed there, feeding on plant juices and can cause moderate to severe defoliation and fruit drop. The most commonly occurring scales are "armored" or hard scales like purple scale (Figure 22), snow scale (Figure 23), red scale (Figure 25), and "soft" scales like Caribbean black scale (Figure 24) and cottony cushion scale (Figure 26), which stimulate sooty mold fungus. Tiny wasps that act as a biological control parasitize many of these insects, but, when severe infestation occurs, chemical sprays can be applied, usually when the immature crawler stages are active. When you buy your nursery tree, inspect it carefully for infestation by scales. They are readily observed, if present, on leaves and twigs.

Chewing insects, including grasshoppers (Figure 27 ), crickets, root weevils (scalloped leaves indicate feeding of adults, Figure 28), katydids (Figure 29) and caterpillars, cause occasional leaf damage, especially on young trees, and fruit drop. Katydid eggs, laid along the leaf margin, usually arouse the interest of home gardeners. Orange dogs (the caterpillar form of a large black and yellow swallowtail butterfly) may grow to a length of 2 
inches. During summer and early fall these caterpillars can completely defoliate young trees (Figure 30). During these times they can be easily picked off leaves by hand or with tweezers.

Citrus leafminers, now widespread in Florida, cause damage to newly emerged leaves and shoots. The larval form of this tiny moth eats a serpentine tunnel through leaves, twigs and, occasionally, fruit (Figure 31).

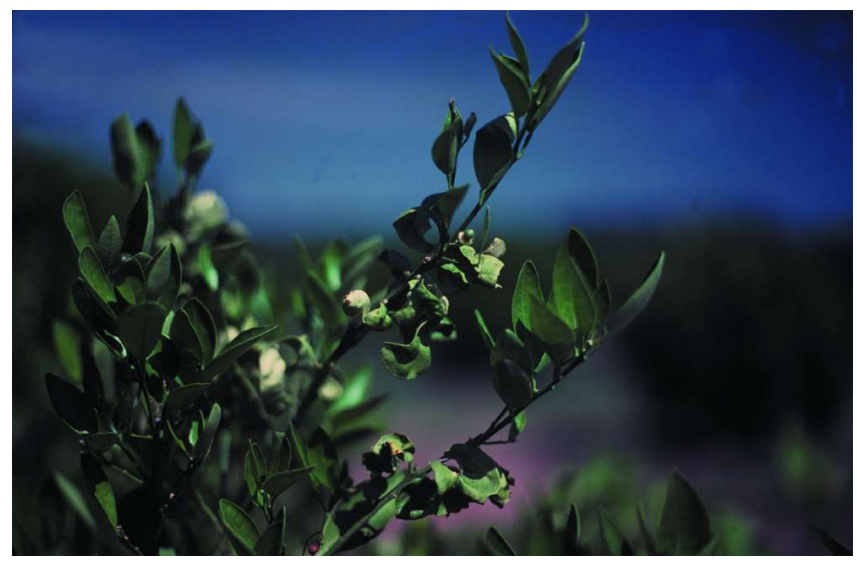

Figure 15. Aphids cause cupping, curling and distortion of young leaves.

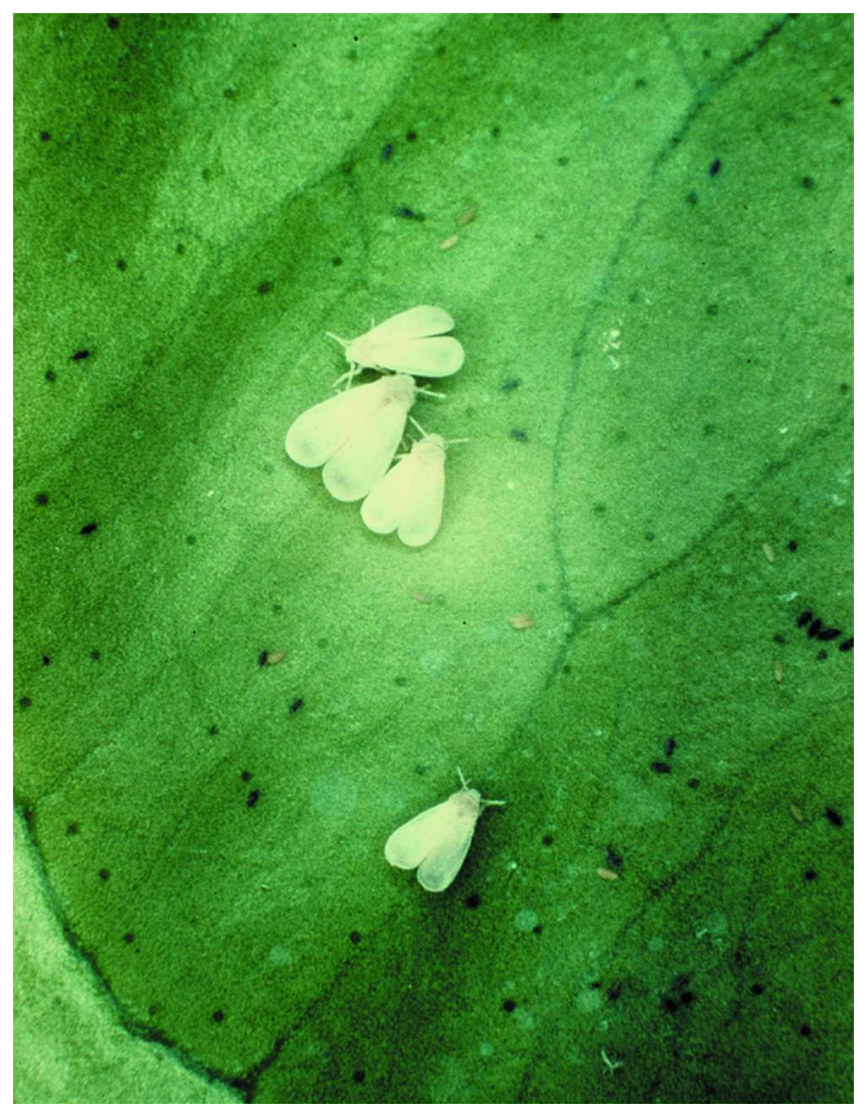

Figure 16. Whiteflies feeding on leaves.

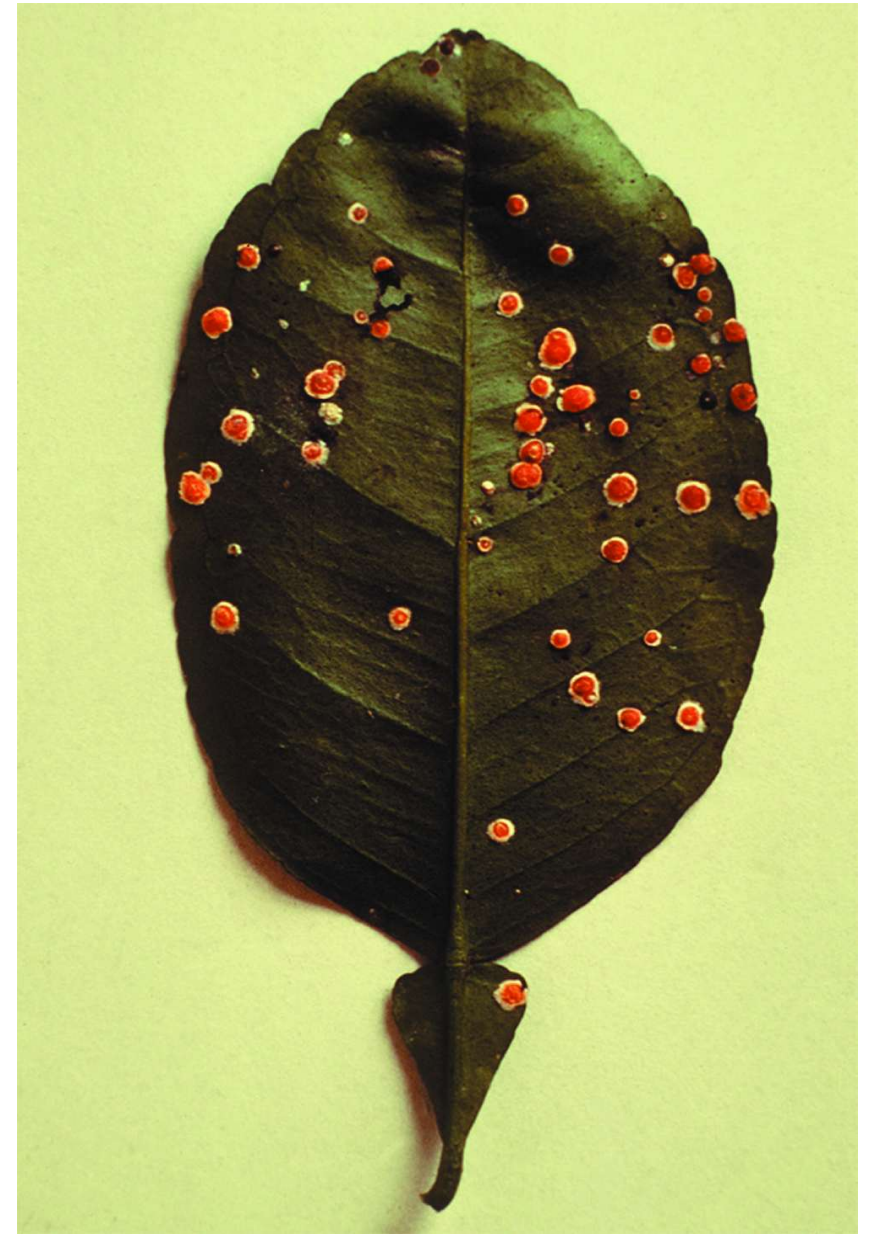

Figure 17. Beneficial orange-red fungus parasitizes of white flies.

\section{Disorders}

A combination of unfavorable environmental conditions and irregular fertilization and irrigation practices have been associated with the following fruit disorders:

- granulation or drying of the juice sacs within fruit,

- creasing (depressed areas in the peel), and

- fruit splitting and fruit drop.

Granulation usually occurs on rapidly growing fruit and excessively large fruit. While Valencia oranges are most frequently affected, other oranges, grapefruit, and tangerine cultivars are subject to this malady as well, especially when budded on rough lemon and trifoliate rootstocks. Good fertilization and nutrition practices and early seasonal harvesting may alleviate this problem. 


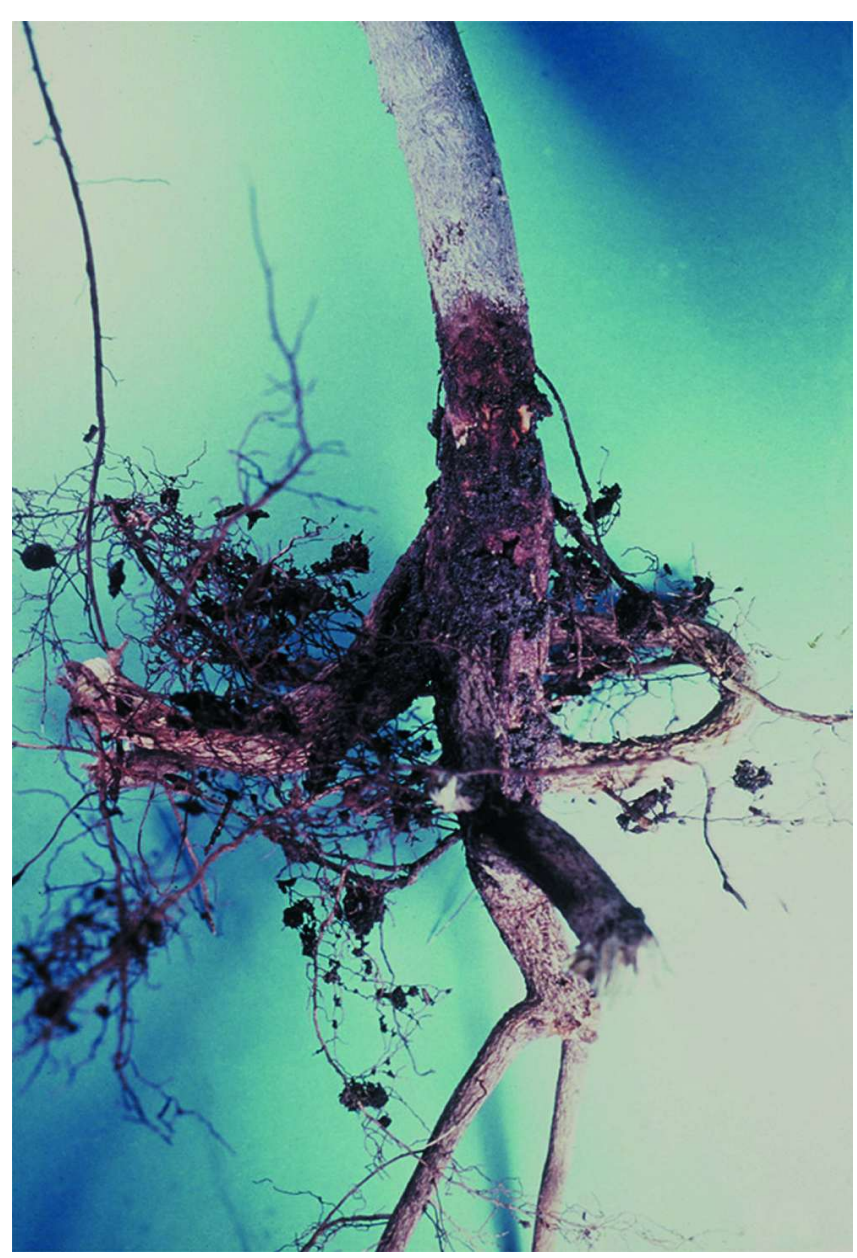

Figure 18. Fire ant damage on roots and trunk of young tree.

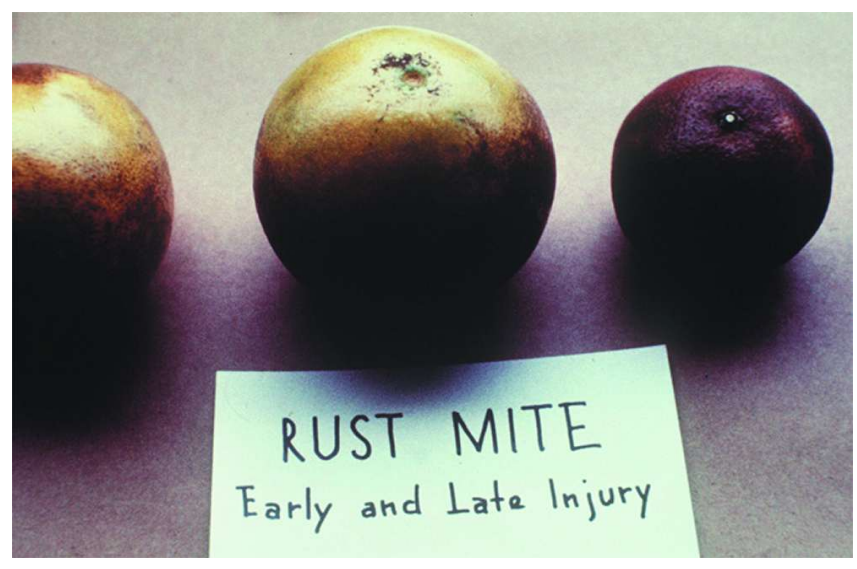

Figure 19. Rust mite damage.

Creasing occurs when tissue in the spongy white layers beneath the peel separates, causing depressed areas in the peel itself (Figure 32). This condition doesn't affect internal fruit quality. Creasing may be related to unusual nutrition, temperature, and moisture conditions, and can be avoided by good cultural practices.

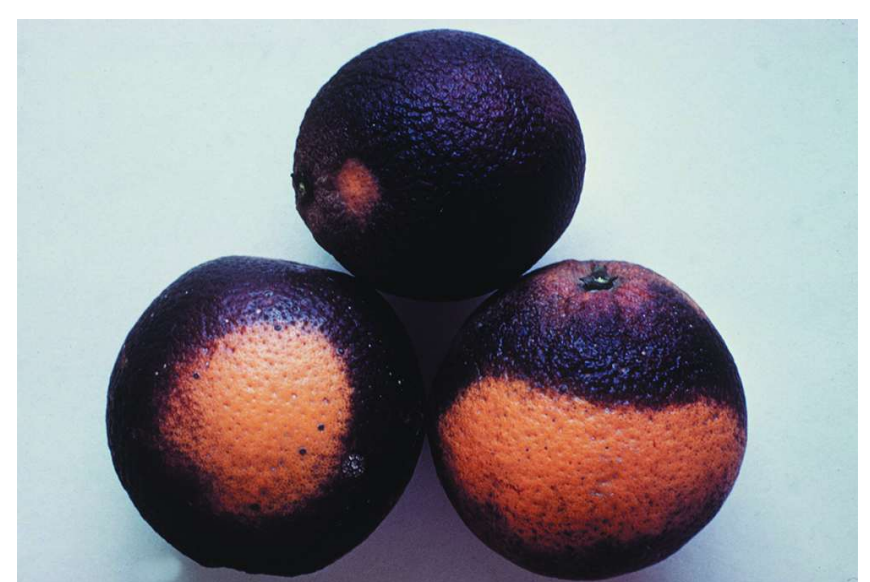

Figure 20. Rust mite damage except in clearly demarked areas in direct sunlight.

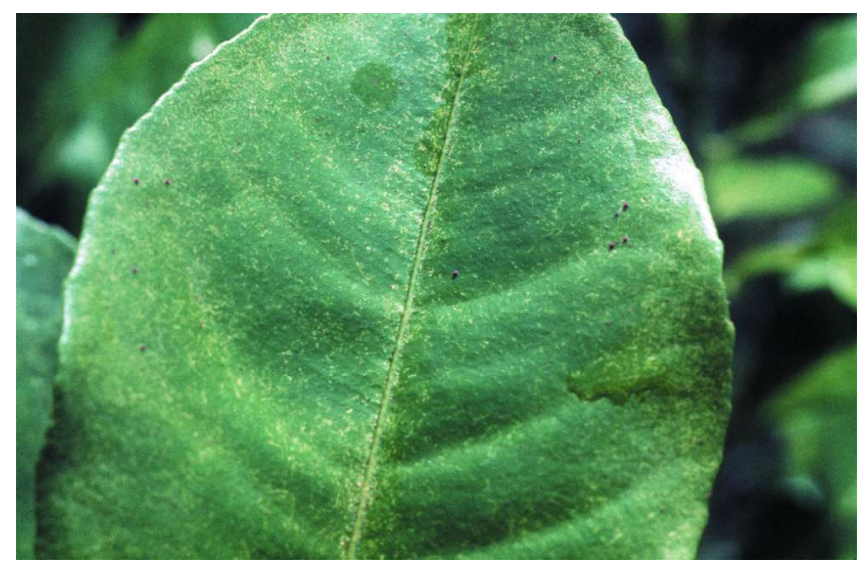

Figure 21. Spider mites cause stippling or etching on leaves.

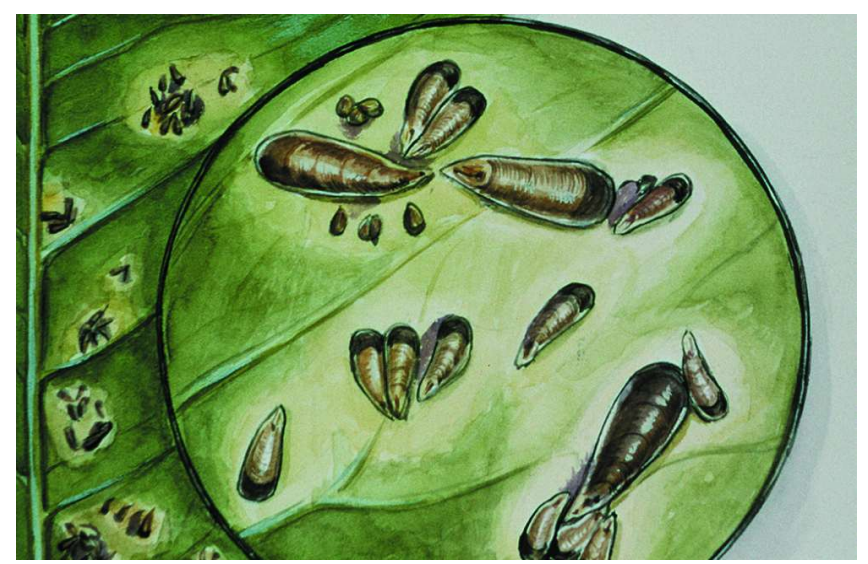

Figure 22. Purple scale is brown to purple color with a comma-like oyster shape.

Fruit splitting usually associated with irregular development and expansion of fruit cells can best be prevented by uniform irrigation and fertilization practices (Figure 33). 


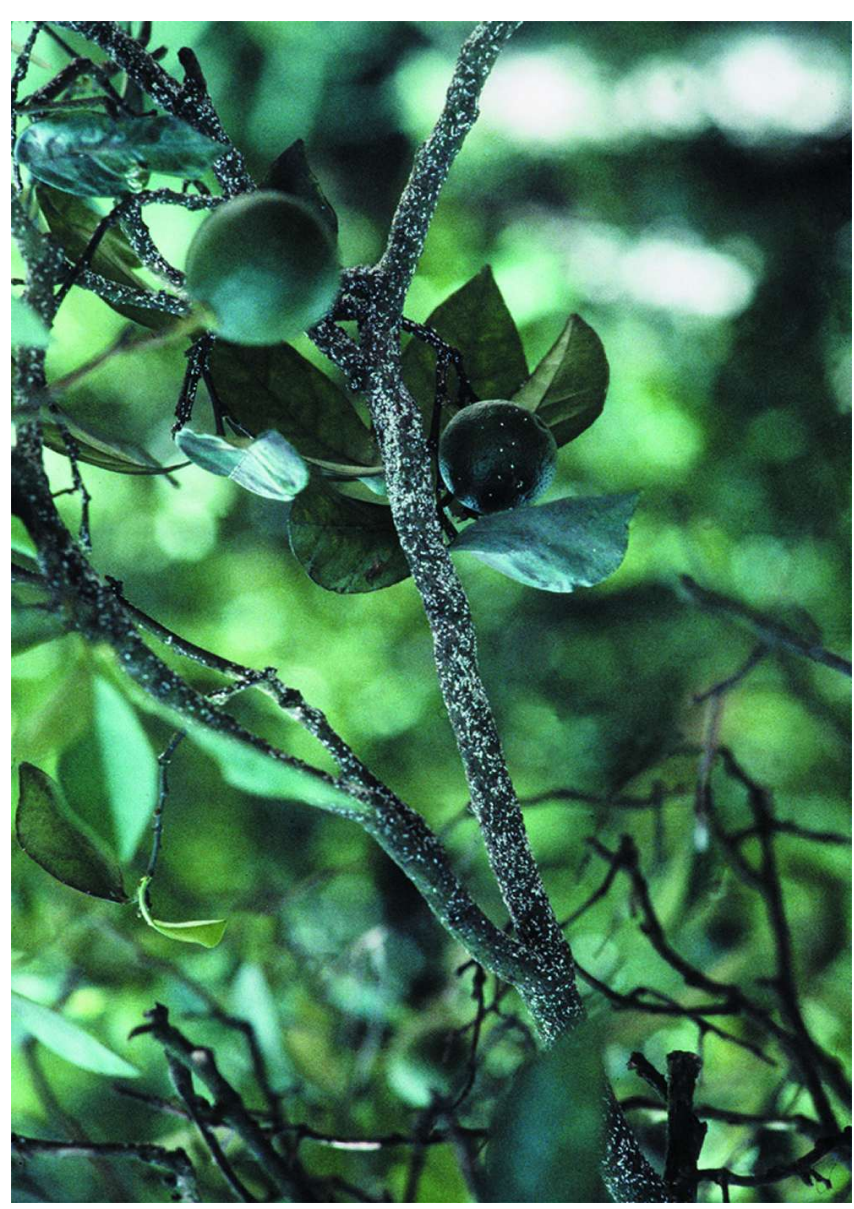

Figure 23. Snow scale gives infected twigs and branches a white-washed look.

Some fruit drop occurs on most citrus cultivars, usually within 4 to 8 weeks of bloom-it's a natural process that allows the tree to adjust its fruit load for the coming season when an unusually large number of fruit have been set. Other cultivars (like Pineapple oranges and navel oranges) commonly drop fruit again, later in the season.

Even if you fertilize and irrigate your trees regularly, you may still see some nutritional deficiencies that warrant foliar sprays. Again, your county extension agent can be helpful in this situation.

\section{Nitrogen Deficiency}

Nitrogen deficiency is a general leaf yellowing (Figure 34) that commonly occurs in some cultivars like Orlando tangelos during late winter and early spring. Another form of nitrogen deficiency, in which the main veins turn yellow, occurs when the canopy receives an inadequate supply of nitrogen. Both forms of nitrogen deficiency may be due to poor

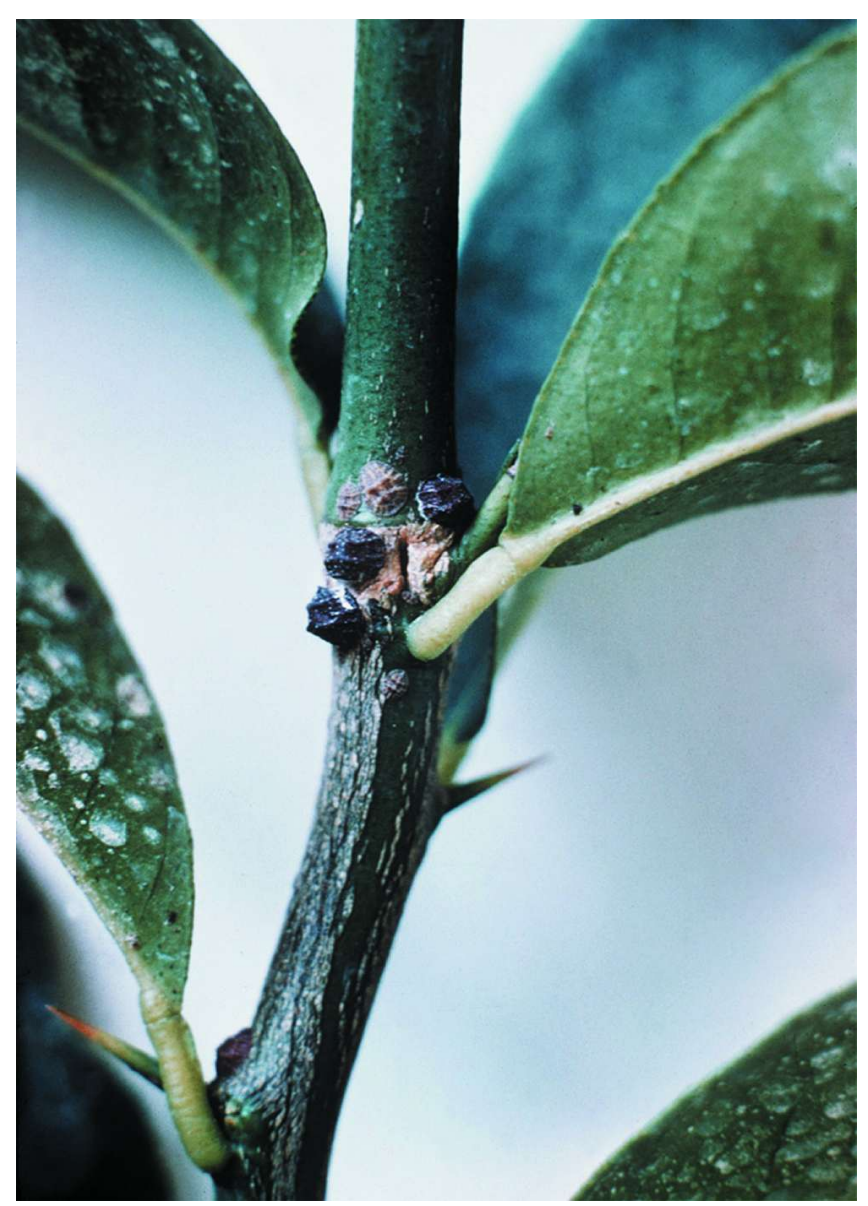

Figure 24. Caribbean black scale has an $\mathrm{H}$-shaped longitudinal ridge.

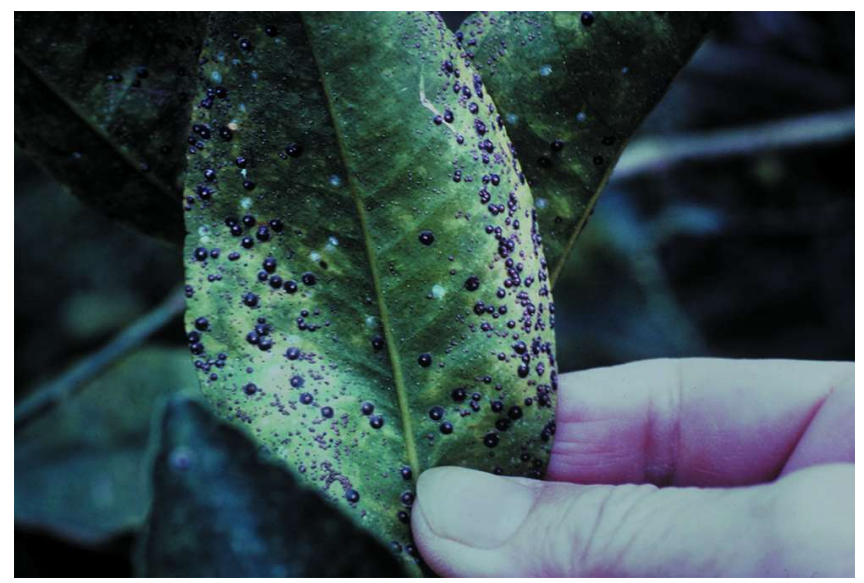

Figure 25. Red scale has a central, light nipple within a reddish-brown ring.

fertilization practices or to other, more serious problems: foot rot, root rot, nematode damage, etc. These affect the movement of nutrients from roots to the canopy. If you maintain and monitor your fertilization practices and the tree still does not respond, investigate these other possibilities. 


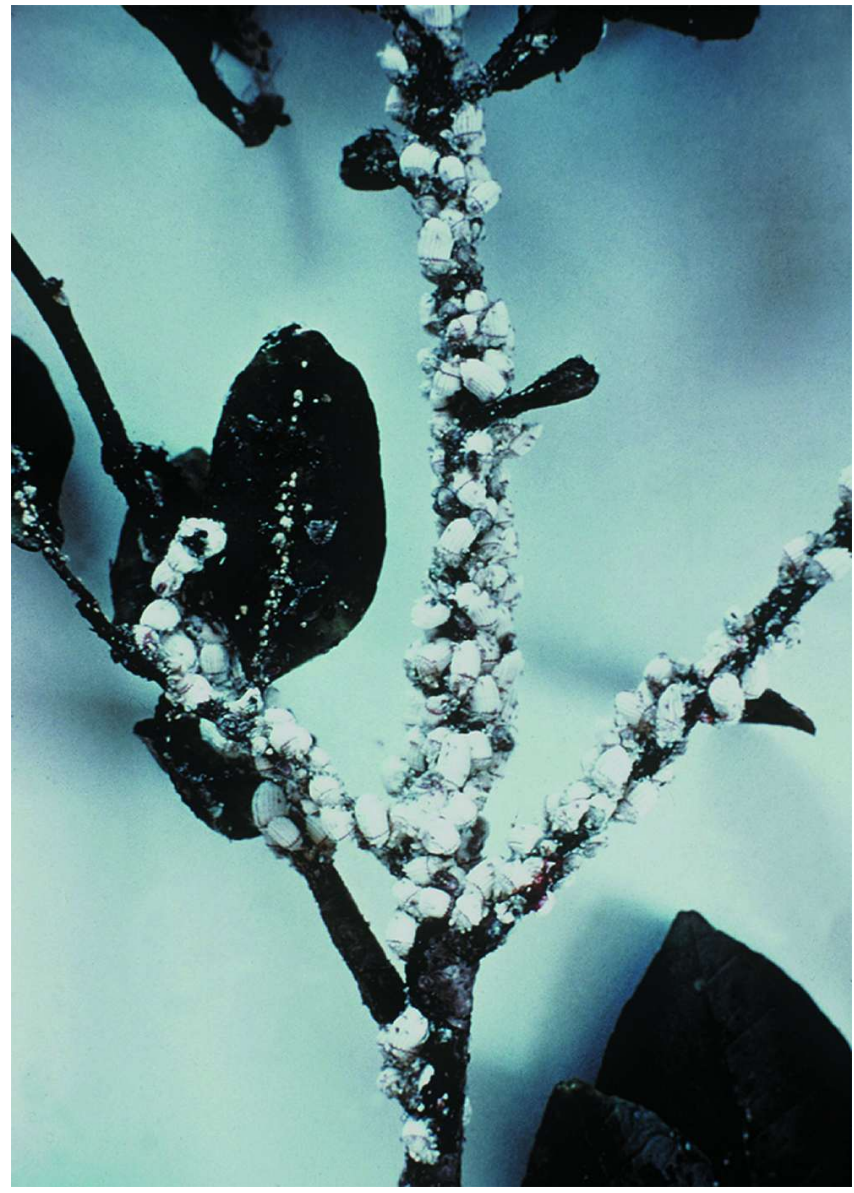

Figure 26. Cottony cushion scale is usually covered with waxy secretions; commonly parasitized by lady beetles.

\section{Magnesium and Manganese Deficiencies}

Magnesium deficiency is characterized by an inverted, green, $v$-shaped area at the base of the leaf, with the rest of the leaf turning yellow (Figure 35). In manganese deficiency, bands along the midrib (the main vein running the length of the leaf) remain green; areas between the veins turn light green (Figure 36).

\section{Zinc and Iron Deficiencies}

Zinc deficiency also produces leaves that have irregular green bands along the midrib and lateral or side veins but can be distinguished from magnesium-deficient leaves because of their small, narrow size, pointed tips and the pattern of leaf clusters or rosettes caused by decreased stem elongation between leaf buds (Figure 37).

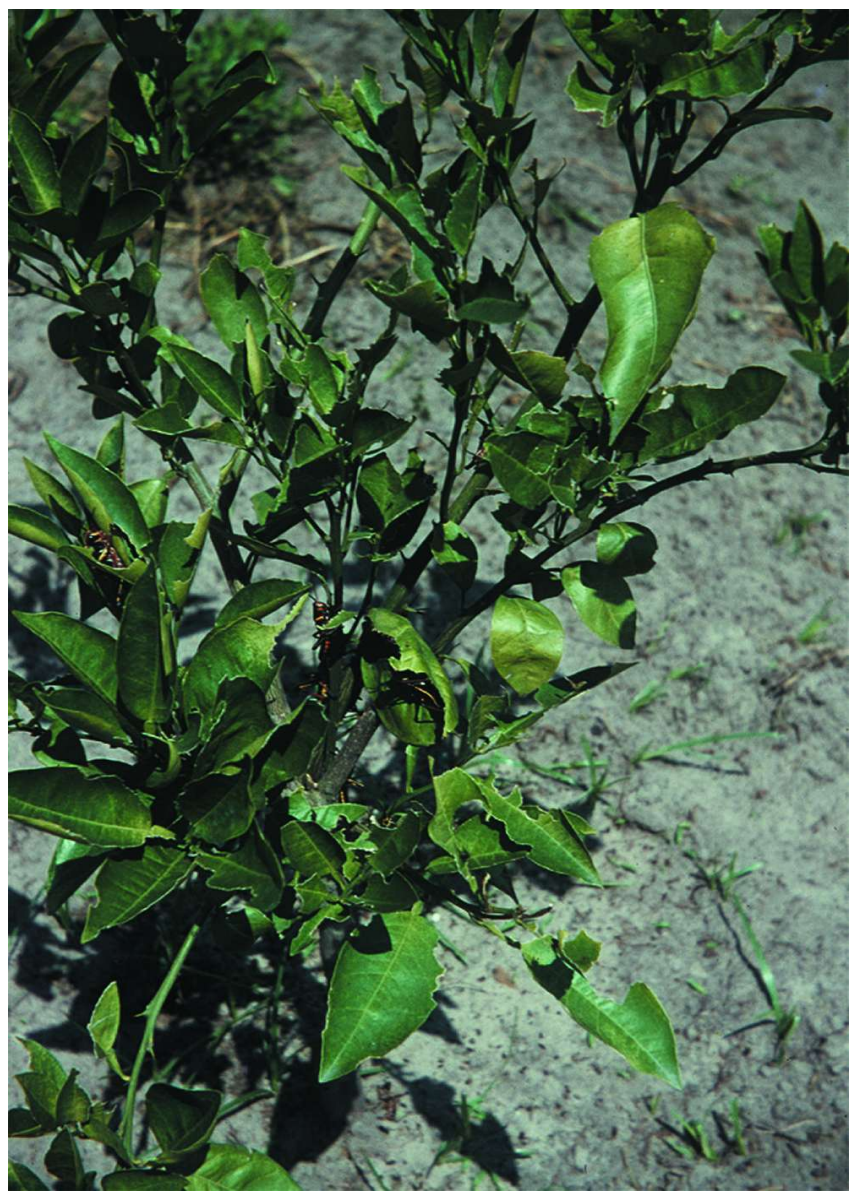

Figure 27. Lubber grasshopper.

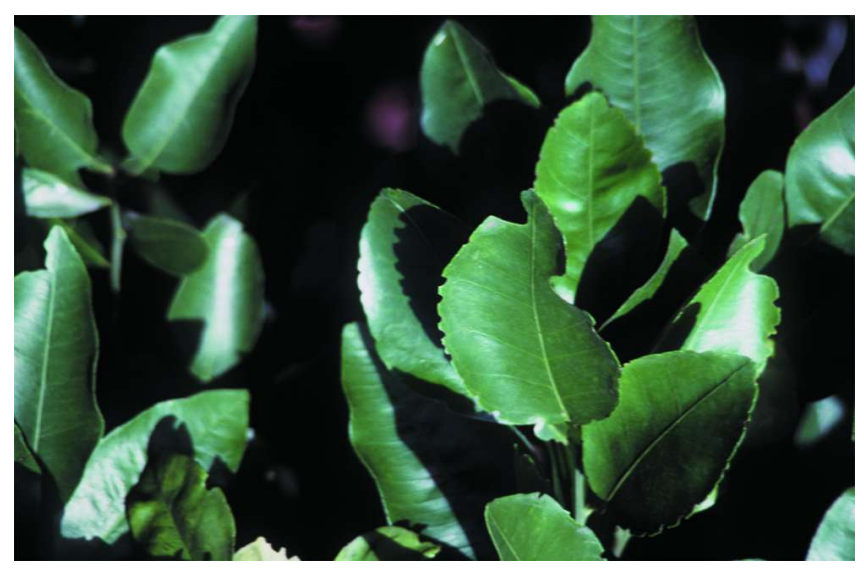

Figure 28. Scalloped leaves showing where adult root weevils fed.

Iron deficient leaves have a very fine network of green veins all over the leaf (Figure 38). Nitrogen and magnesium deficiency symptoms usually occur on the oldest leaves whereas zinc and manganese symptoms usually occur on the youngest leaves. Nitrogen and magnesium deficiencies can be corrected by applying a complete fertilizer containing 


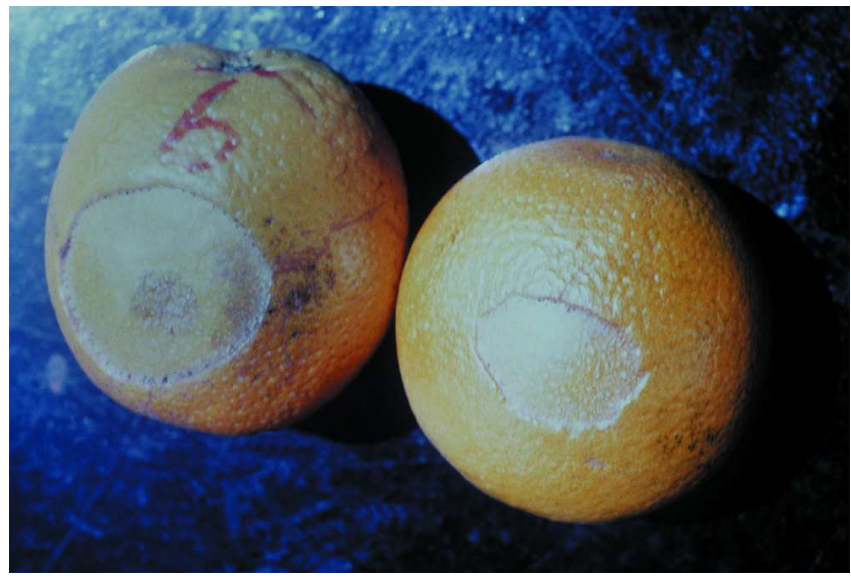

Figure 29. Katydid damaged on fruit showing depressions below uninjured area.

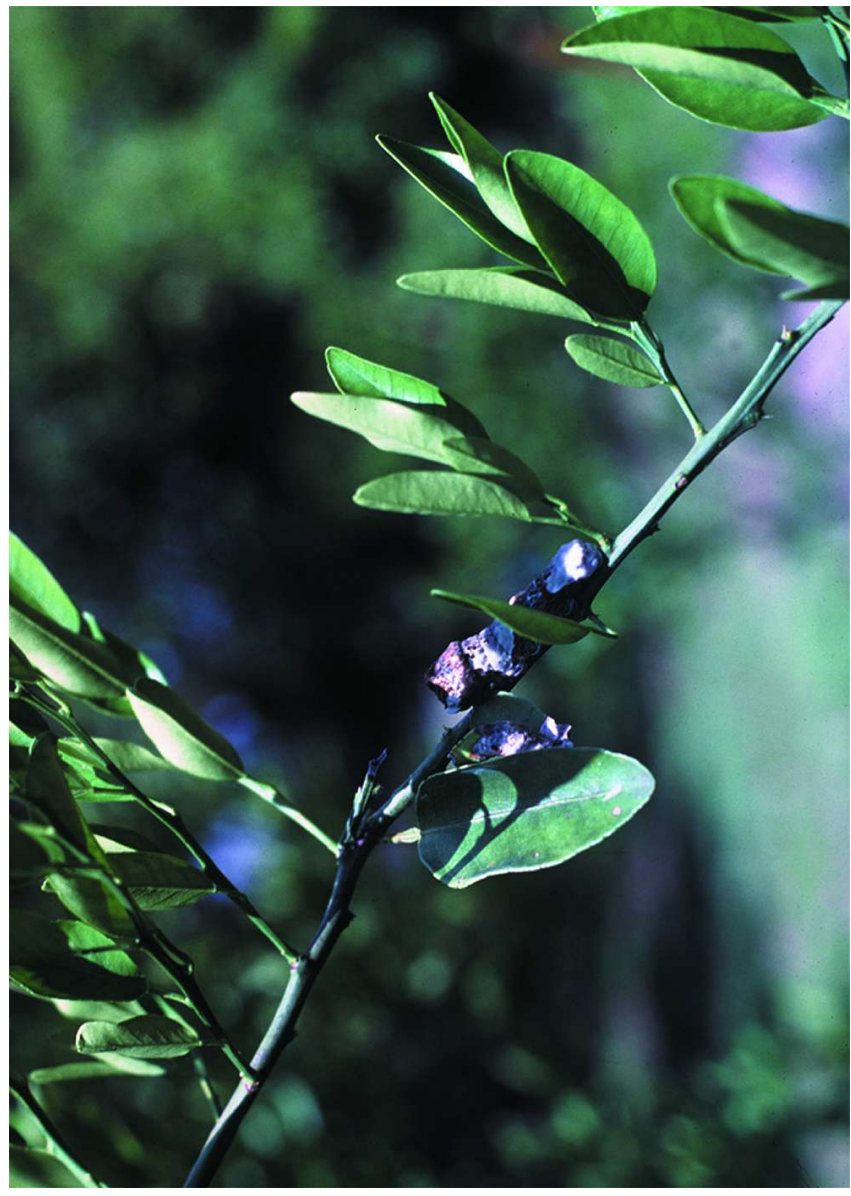

Figure 30. Orange dog caterpillars chew entire leaves.

micronutrients whereas zinc and manganese usually require foliar sprays containing these micronutrients.

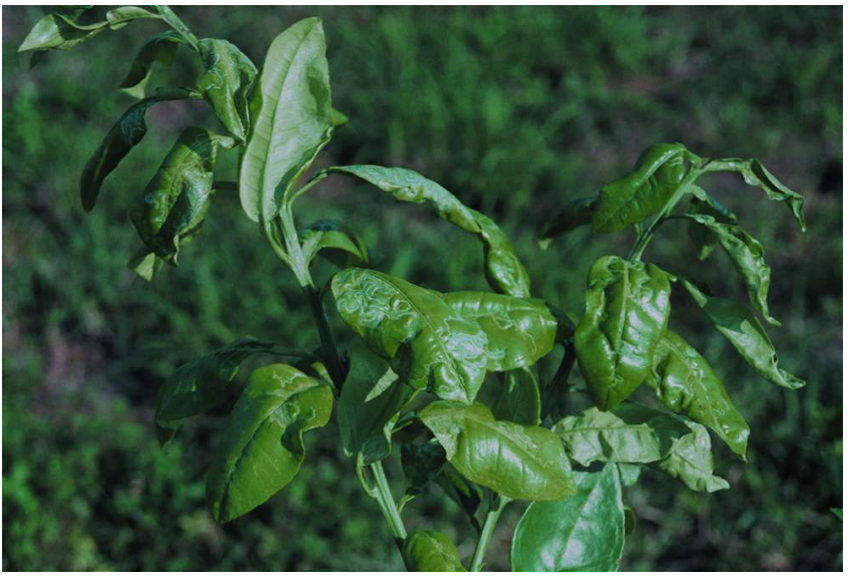

Figure 31. Citrus leafminers damage young leaves and twigs, and sometimes damage fruit.

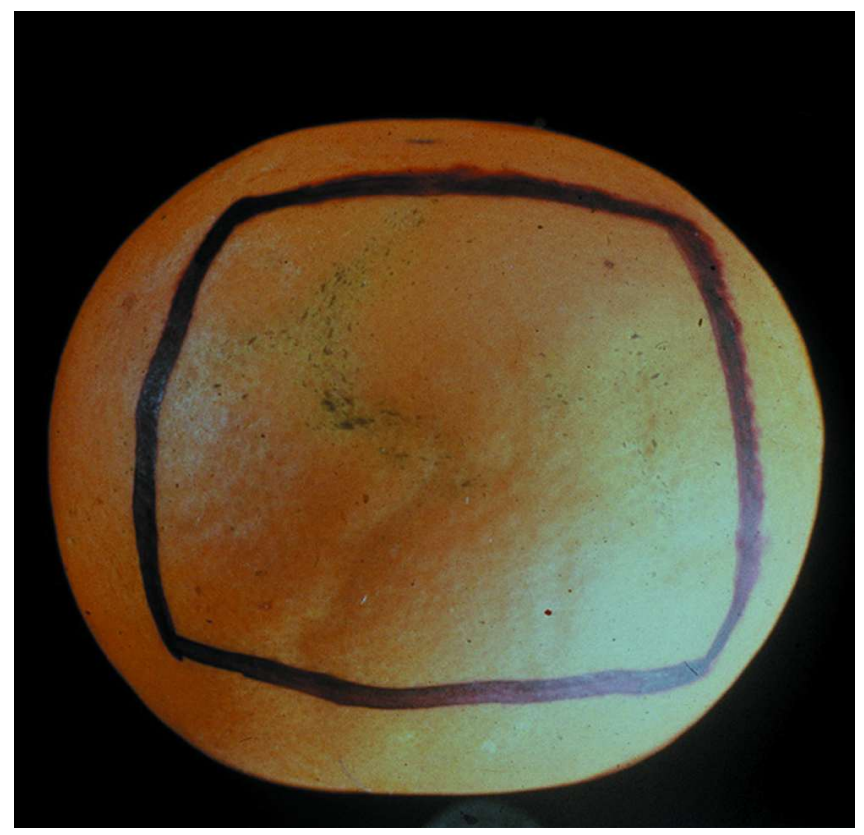

Figure 32. Creasing: depression in the peel.

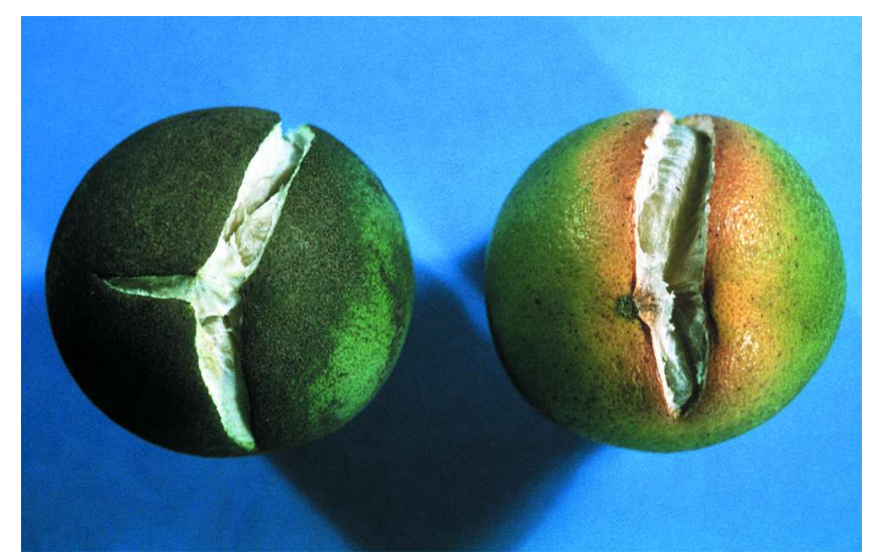

Figure 33. Fruit splitting. 


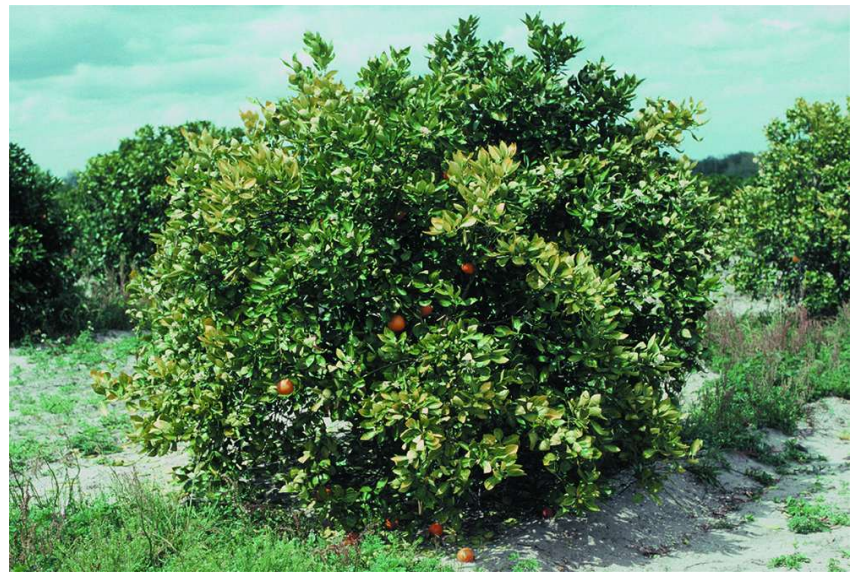

Figure 34. Nitrogen deficiency causes leaf yellowing.

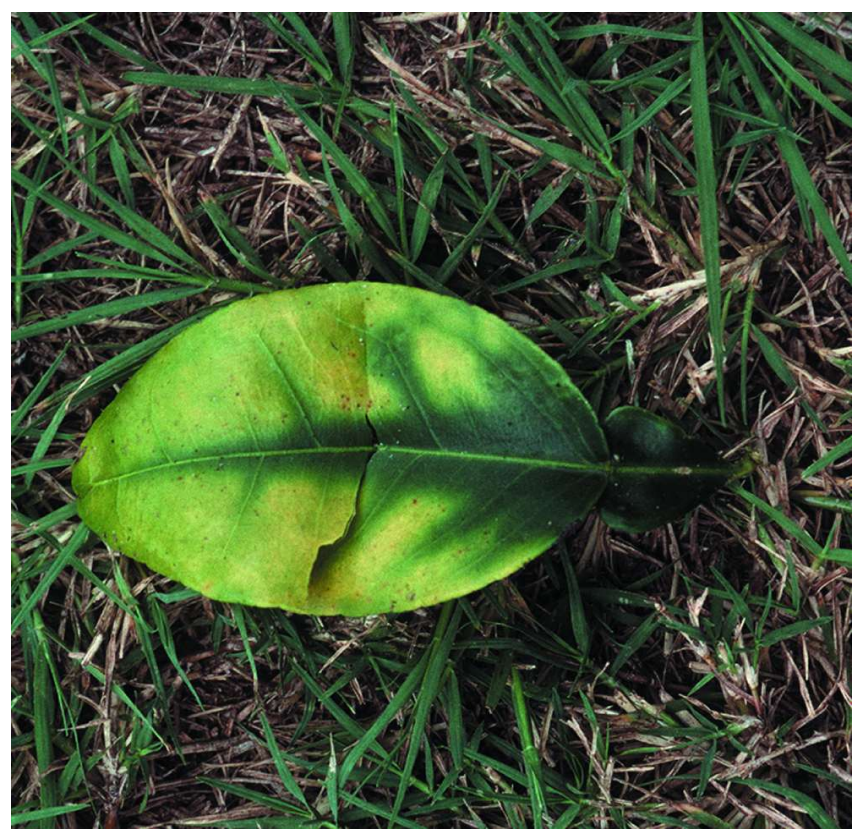

Figure 35. Magnesium deficiency: inverted V-shaped area near leaf base.

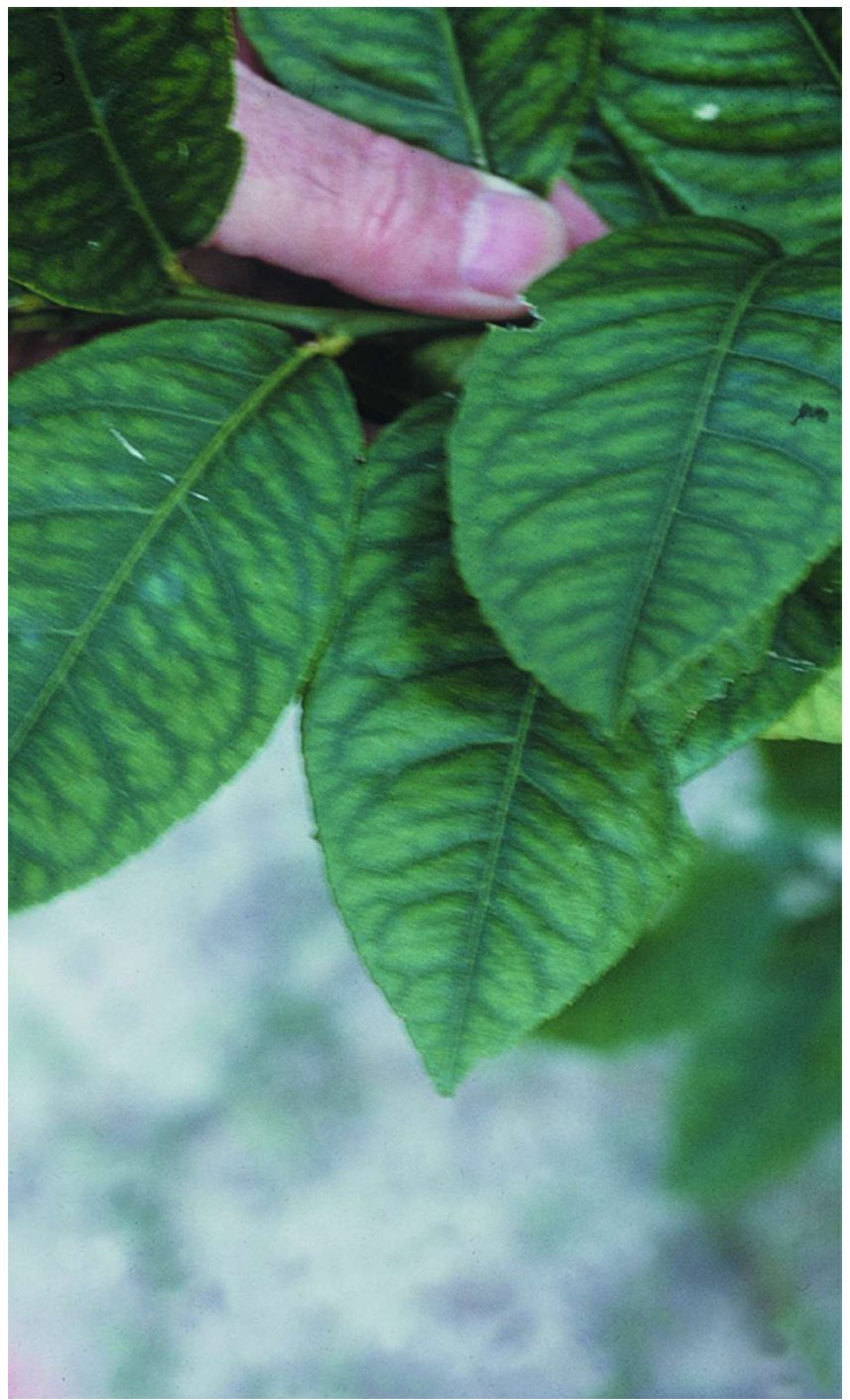

Figure 36. Manganese deficiency: mangy, irregular bands along the midrib remain green.

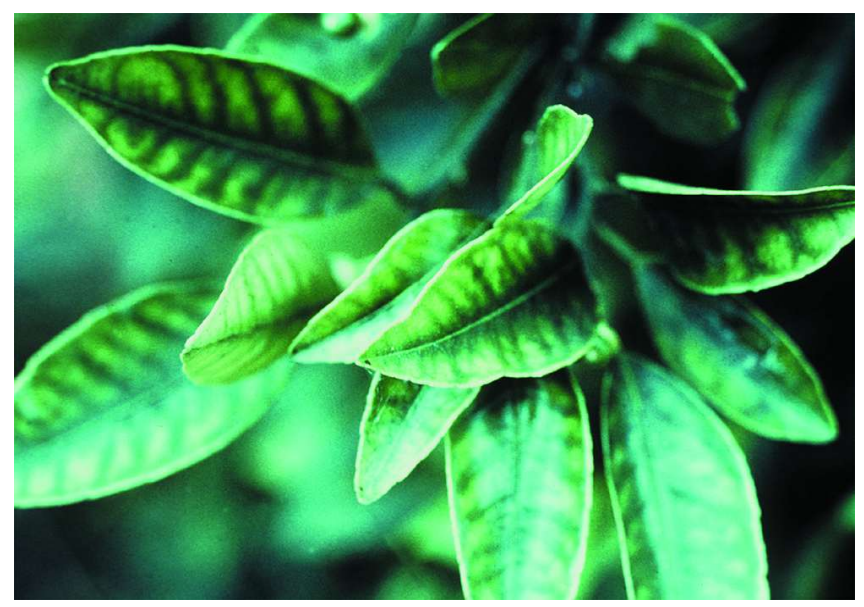

Figure 37. Zinc deficiency small, narrow leaves in cluster. 


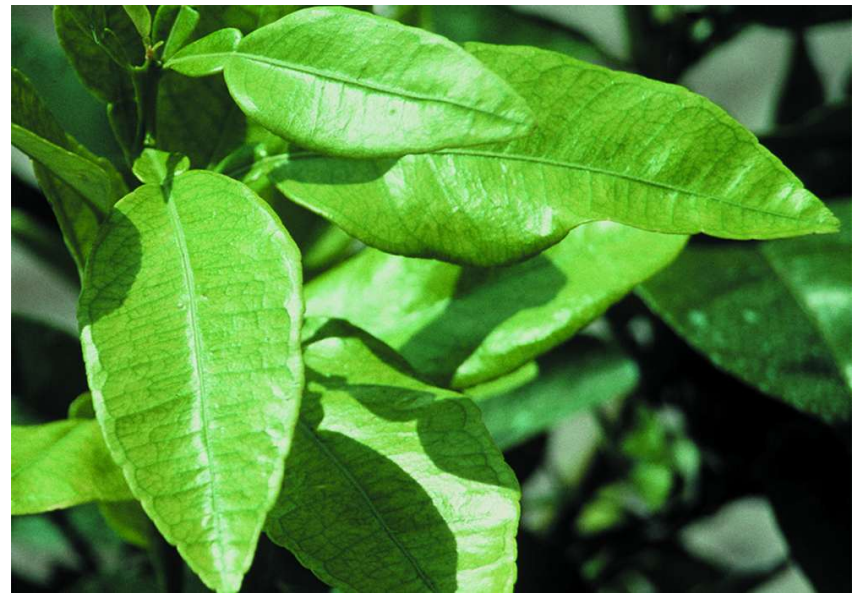

Figure 38. Iron deficiency: a fine network of green veins all over the leaf. 